\title{
Association of Vegetable Consumption with Nutritional Status in Adolescents in Mexico City
}

\author{
Claudia Cecilia Radilla Vázquez¹, Salvador Vega y León ${ }^{2 *}$, Rey Gutiérrez Tolentino², \\ María Radilla Vázquez ${ }^{3}$, Marcela Vazquez Francisca², Clemente Sierra Cortés², \\ Marta Coronado Herrera ${ }^{2}$, Juan Gabriel Rivera Martínez ${ }^{4}$ \\ ${ }^{1}$ Department of Health Care, Metropolitan Autonomous University (UAM-X), Mexico City, Mexico \\ ${ }^{2}$ Department of Agricultural and Animal Production, Metropolitan Autonomous University (UAM-X), Mexico City, Mexico \\ ${ }^{3}$ Metropolitan Autonomous University, Mexico City, Mexico \\ ${ }^{4}$ Department of Reproductive Biology, Autonomous Metropolitan University (UAM-I), Mexico City, Mexico \\ Email:*svega@correo.xoc.uam.mx
}

How to cite this paper: Radilla, V.C.C., Vega, L.S., Gutiérrez, T.R., Radilla, V.M., Vazquez, F.M., Sierra, C.C., Coronado, H.M. and Rivera, M.J.G. (2016) Association of Vegetable Consumption with Nutritional Status in Adolescents in Mexico City. Food and Nutrition Sciences, 7, 1414-1422. http://dx.doi.org/10.4236/fns.2016.714128

Received: November 10, 2016

Accepted: December 26, 2016

Published: December 29, 2016

Copyright $\odot 2016$ by authors and Scientific Research Publishing Inc.

This work is licensed under the Creative Commons Attribution International

License (CC BY 4.0).

http://creativecommons.org/licenses/by/4.0/

\begin{abstract}
It has been documented that increased vegetable consumption is associated with preventive effects in some public health problems such as obesity and some chronic noncommunicable diseases. The aim of this study was to determine the association of nutritional status with vegetable consumption in adolescents from Technical High Schools in Mexico City. A sample of 2368 adolescents was obtained who were applied a questionnaire of frequency food consumption and anthropometric measurements were taken, the nutritional diagnosis was obtained with Who Anthro Plus program. The data obtained were analyzed with the statistical package SPSS version 20.0 for Windows Statistics ${ }^{\oplus}$. When the correlation of frequency consumption of vegetables with nutritional status, in the final phase, It found that teens who never ate vegetables were more likely to develop obesity (36.0\% GI and $36.10 \% \mathrm{GC}$ ), compared with teens who consumed daily (8.9\% GI and $2.10 \%$ GC), existing difference highly significant. The teenagers of the Technical High School in Mexico City in the intervention group presented a basal daily intake of $15.7 \%$ and after the intervention their intake increased to $21.3 \%$. With respect to the control group it started with a daily intake of $12.6 \%$ to $14.9 \%$ increasing it. An increase was achieved in the daily consumption of vegetables in adolescents of both groups so it is concluded that the intervention was successful.
\end{abstract}

\section{Keywords}

Adolescents, Vegetables, Overweight, Obesity, Mexico

\section{Introduction}

Vegetables consumption is an essential part of a healthy diet during growth and devel- 
opment of children and adolescents. So habits, preferences and healthy food choices acquired during childhood and adolescence remain throughout life. The interest in the increase of this consumption is associated with preventive effects in some public health problems such as obesity, cardiovascular diseases and certain cancers [1].

Some research has shown the protective effect of vegetable consumption on chronic noncommunicable diseases (NCDs) [2].

It has been considered that consumption of vegetables reduces obesity because it increases the amount of fiber, decreases fat intake and energy density of the diet, and increases satiety [3].

The World Health Organization recommends a daily consumption of $400 \mathrm{~g}$ from vegetables and fruits for an adequate supply of fiber and to meet the needs of micronutrients. This daily requirement is satisfied by eating five servings of vegetables and fruit per day [4].

The Institute of World Cancer Research Fund suggests a daily intake of $600 \mathrm{~g}$ of vegetables and fruits [5], while the American Heart Association recommends eating vegetables between 2.5 to 3 cups per day [6].

Overweight and obesity are closely related to the development of chronic diseases in Latin America, $70 \%$ of all deaths and $60 \%$ of the burden of disease due to NCDs; vegetable consumption, and contribute to their prevention, exerts beneficial effects by providing micronutrients such as vitamins $\mathrm{A}, \mathrm{C}$ and folic acid, plus minerals that contribute to health maintenance [7].

So the aim of this study was to determine the association of nutritional status with vegetable consumption in adolescents of the Technical High Schools in Mexico City.

\section{Materials and Methods}

Study design

This was a randomized controlled trial school-based intervention designed, reviewed and approved by the Doctoral of Biological Sciences and Health Research Commission of Autonomous Metropolitan University.

In first place the Ministry of Education was contact and approve to do the protocol in their schools, in addition, parents provided written informed consent allowing their adolescents to participate in the study. The research were carried out over 2012-13 to 2014-15 school years.

School recruitment: Only public technical high schools meeting the following criteria were considered for study inclusion: 1) located in Mexico City; 2) classified by the Ministry of Education as a schools with scholar doctor in it; 3) being a schools with morning and evening shift; 4) possessing the minimum facilities necessary for the intervention implementation. Of a preliminary list of 119 schools located in the urban area of Mexico City, provided by the Technical High School General Direction by the Ministry of Education in Mexico City, 75 schools were selected initially because partially met the inclusion criteria having a scholar doctor in their installations, then in a new selection included the schools with a morning and evening shifts and facilities necessaries for the intervention, the final list include 56 eligible schools. From the 56 eligible 
schools that met the inclusion criteria the selection adjust by the minimum effective sample size, calculated on the assumption of simple random sampling, by used the Murray-Larry formula, and obtained a final sample with 16 schools.

Selection criteria and randomization of units

From the 16 selected schools than met de inclusion criteria and agreed to participate in the study by committing the study needs, them were randomly selected used an aleatory number generator with binomial distribution with a 0.28 probability and assigned to one of two condition: intervention $(n=8)$ and Control $(n=8)$.

The intervention strategies were implemented in 8 intervention schools and were targeted to teenagers recruit in first grade of high school during the first year of intervention with a follow-up for three years of study inside the selected schools.

Student recruitment: A total of 2368 students from first year of Technical High School from these 16 schools were randomly selected for outcome evaluation, from initial sample of 3875 students, excluded 1507 due to different circumstances, a flow char of the sample from recruitment to the end of the 3-year intervention period is shown in Figure 1.

Intervention description

A questionnaire of frequency food consumption was applied, and anthropometric measurements were taken using the Who Anthro Plus program, diagnosis of nutritional status was obtained. The data obtained were analyzed with the statistical package SPSS version 20.0 for Windows Statistics ${ }^{\circledR}$. All teens voluntarily participate under the informed consent of their parents or guardians.

The study was conducted in three phases, in the initial phase the basal anthropometric measurements (weight and height) taking and the first application of frequency food consumption questionnaire was conducted. In the intermediate stage, school doctors and science teachers were trained in different topics about physical education in nutrition, obesity, nutritional treatment in overweight and obese adolescents, habits and healthy lifestyles. Also, dietary guidance was provided to students and parents with the use of educational materials. In the final phase the anthropometric measurements were taken again and applied the second time of the frequency food consumption questionnaire. A study subjects were followed for three years (2012-2015).

The sample was divided into two groups, the control group and the intervention group. In the control group only anthropometric averages were taken and carried out the implementation of the frequency food consumption, no nutritional guidance was given. In the intervention group was given nutritional guidance and conducted the training of teachers and school doctors. Both groups received educational support materials; for the intervention group was provided printed materials and the control group digital materials available on pages www.5pasos.sep.gob.mx and www.aprendeconreyhan.com.mx.

\section{Results}

The control group (CG) was made up of 1258 adolescents (53.1\%), while the intervention group (IG) with 1110 adolescents (46.9\%). Two school shifts were considered (morning 


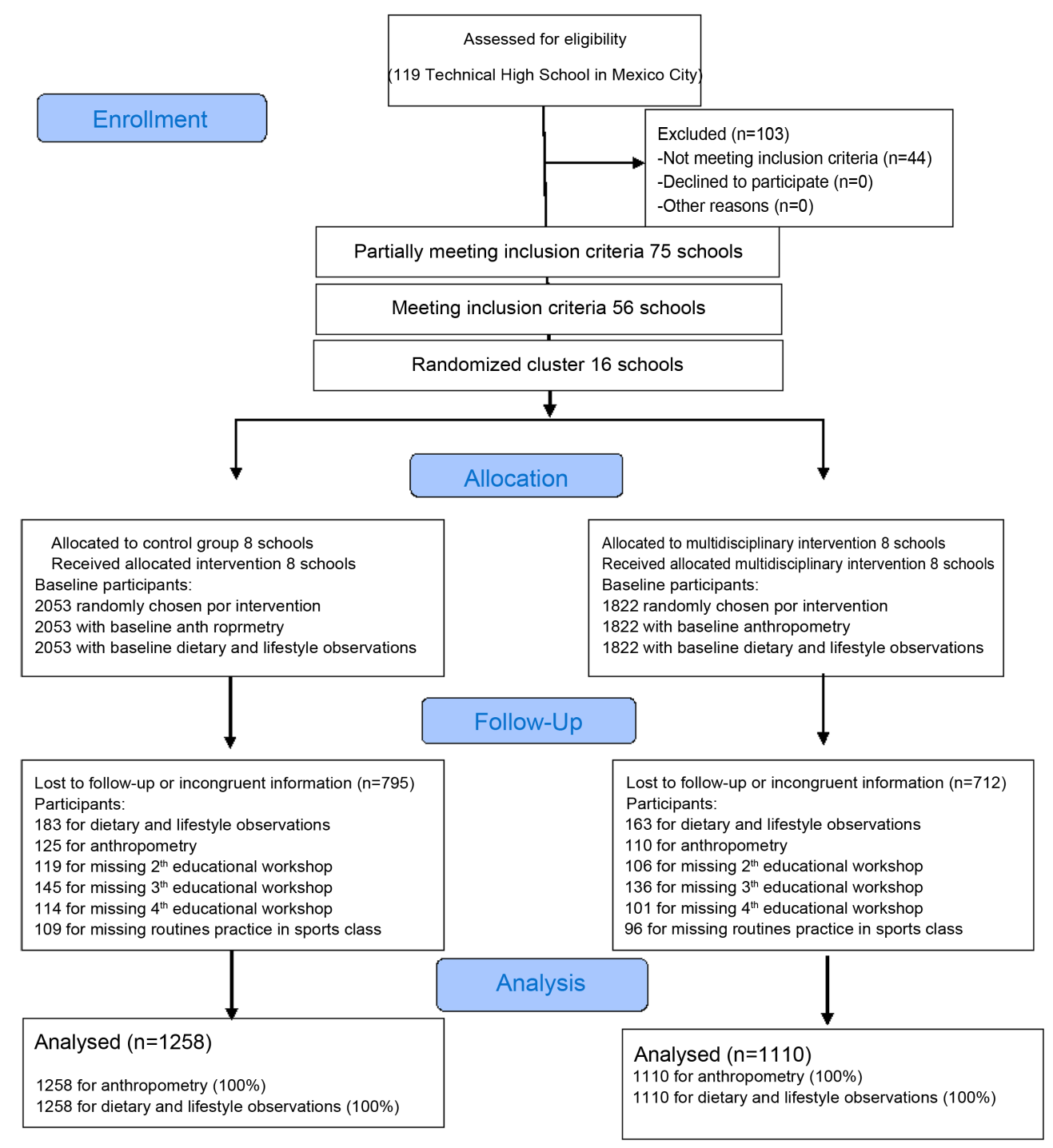

Figure 1. Consort diagram of sample recruitment.

and evening) in the morning shift there was a participation of $60.6 \%$ in IG and $61.5 \%$ in the CG. In the evening shift there was a $39.4 \%$ share and $38.5 \%$, respectively. The $49.0 \%$ and $50.4 \%$ were women, respectively and $51.0 \%$ and the remaining $49.6 \%$ were men, respectively.

The study included adolescents who had to start three-year intervention in the 2012-2013 school years between 11 and 12 years, with a mean age of $11.874 \pm 0.460$ in the IG and an average of $11.843 \pm 0.486$ in the CG.

In the IG, $57.4 \%$ of adolescents have a normal state of nutrition, $26.6 \%$ overweight, $13.8 \%$ obesity and $2.3 \%$ presented thinness. $15.7 \%$ of adolescents consumed vegetables daily, 35.6\% indicated that consuming 1 to 2 days a week, $29.2 \%$ of consumed 3 or 4 days, $13.4 \%$ of consumed 5 or 6 days a week and $6.1 \%$ of adolescents never referred eat vegetables.

In the CG $60.4 \%$ of adolescents have a normal state of nutrition, $24.9 \%$ overweight, 
13.2\% obesity and $1.5 \%$ presented thinness. $12.6 \%$ of adolescents consumed vegetables daily, $35.5 \%$ indicated that consumed 1 to 2 days a week, $32.0 \%$ of consumed 3 or 4 days, $13.0 \%$ of consumed 5 or 6 days a week and $6.9 \%$ of adolescents never referred eat vegetables.

By correlating the frequency of consumption of vegetables with nutritional status, it was found that adolescents who never ate vegetables were more likely to develop obesity $(20.6 \%$ IG and $12.8 \%$ CG), compared with adolescents who consumed daily (12.6\% IG and $10.8 \% \mathrm{CG})$, however, no statistically significant difference was found $(p \geq 0.050)$ (Figure 2).

An increase was achieved in the daily consumption of vegetables in adolescents of both groups. In Figure 2 we can see that the intervention group in the initial phase introduced a daily intake of $15.7 \%$ and after the intervention increased to $21.3 \%$. With respect to the control group it started with a daily intake of $12.6 \%$ incrementing to $14.9 \%$ at the end of the intervention (Figure 3 ).

In order to test whether the intervention influenced the change of eating habits, a comparison was made with the measured frequency consumption of vegetables, for the initial phase and the final phase, for such a result, the $t$ test was applied to samples dependent on the result we can see that the significance is 0.001 and therefore can be stated that the treatment did have effect (Table 1).

After the intervention changes were observed in the nutritional status, where the prevalence of obesity decreased from $13.8 \%$ to $6.1 \%$ (IG) and $13.2 \%$ to $11.9 \%$ (CG), just as the prevalence of overweight was reduced from $26.6 \%$ to $22.8 \%$ (IG) in the CG prevalence of overweight remained similar (Figure 4).

When performing correlation frequency of consumption of vegetables with nutritional

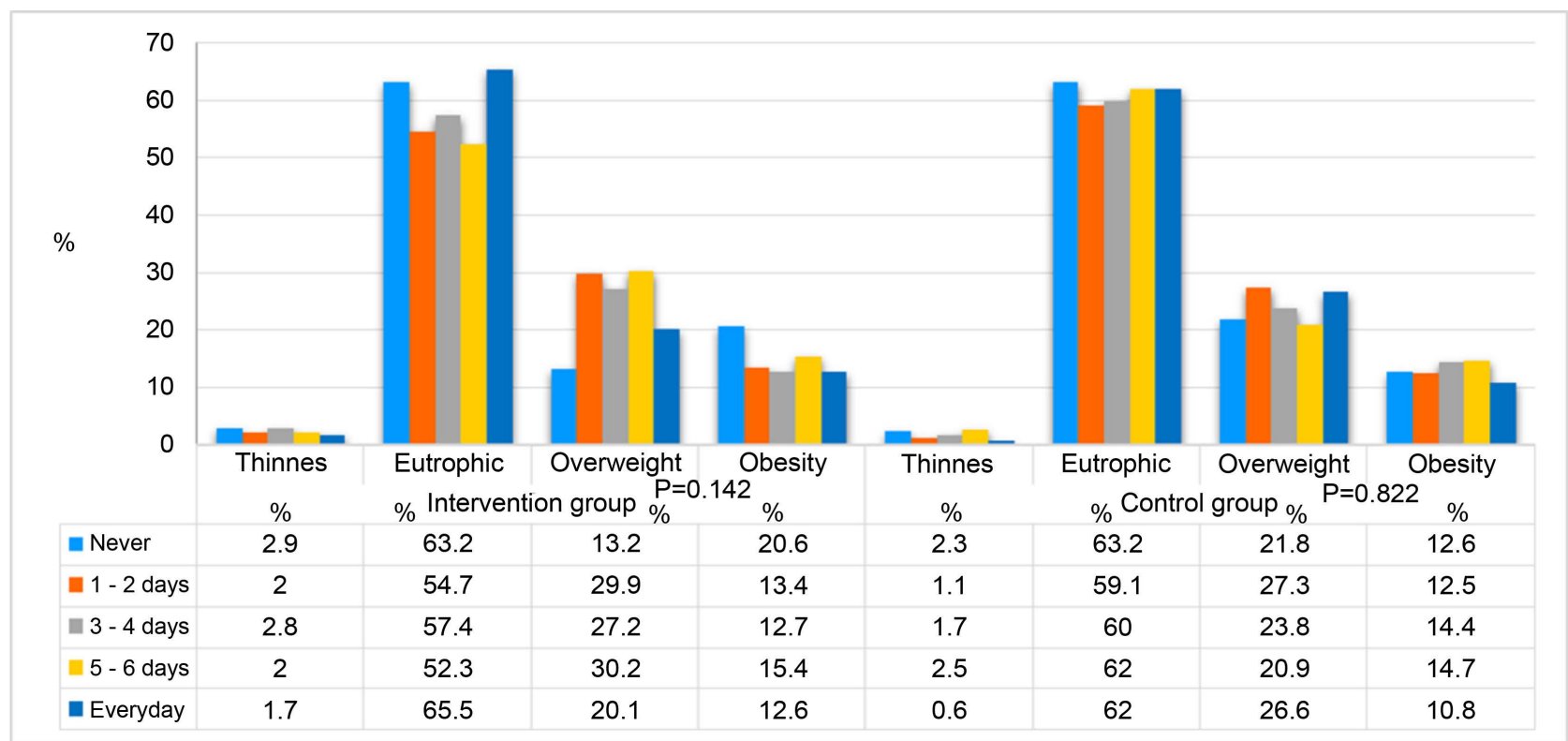

Figure 2. Frequency of vegetable consumption in relation to nutritional status in adolescents of the Technical High Schools in Mexico City. Initial phase. 


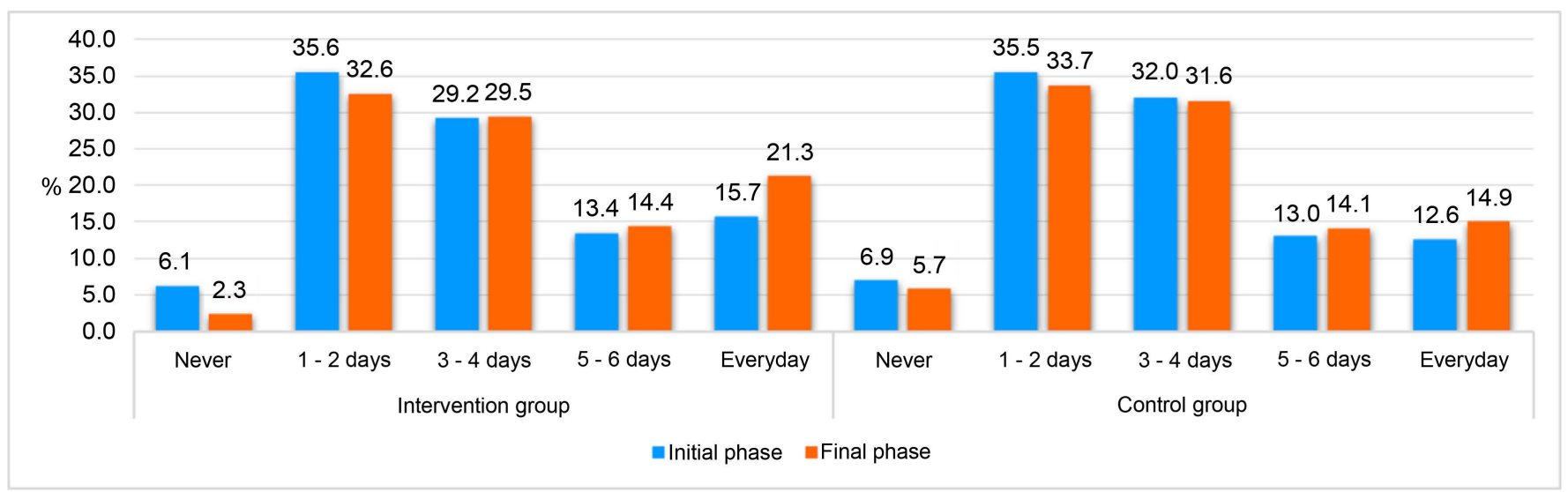

Figure 3. Frequency vegetable consumption in adolescents of the Technical High Schools in Mexico City. Initial and final phase.

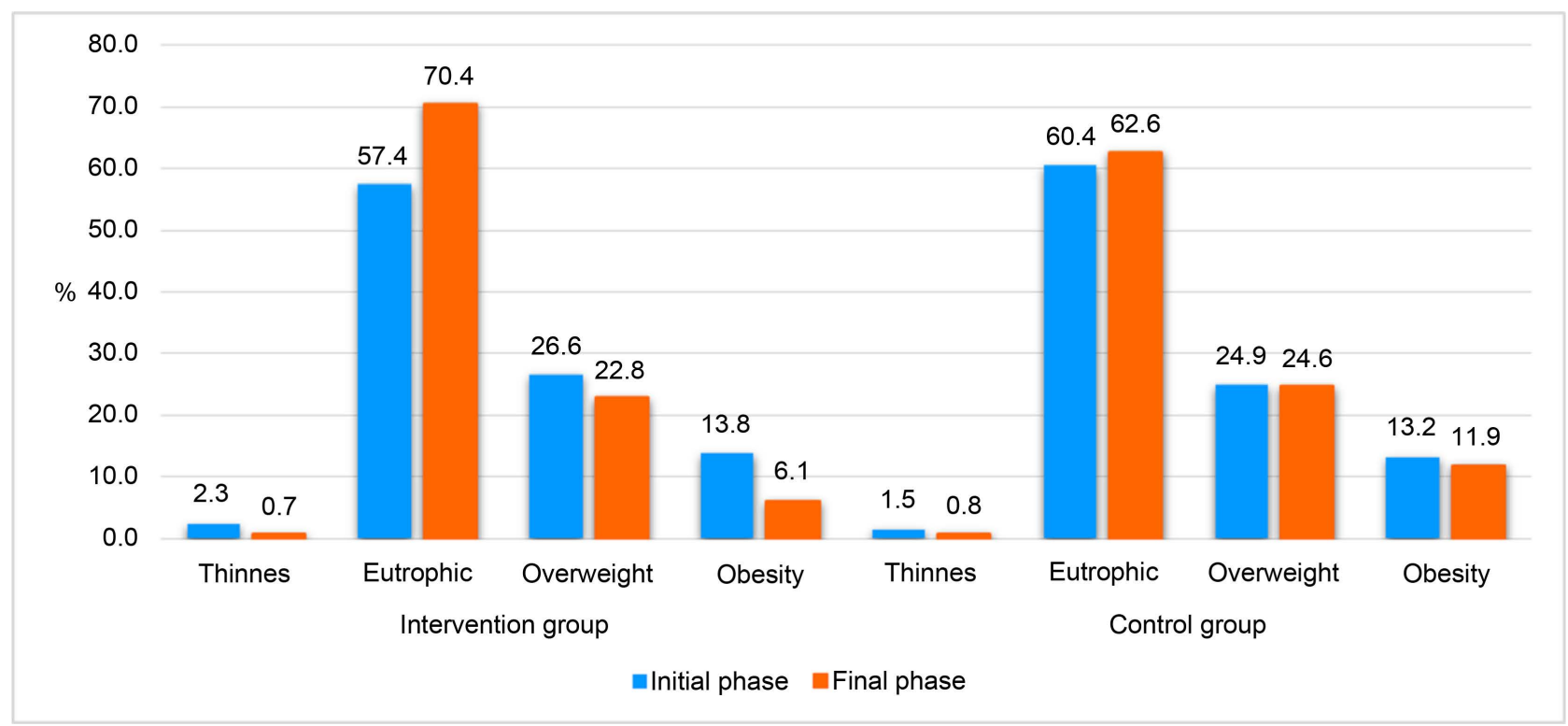

Figure 4. Nutritional status initial phase and final phase in adolescents of the Technical High Schools in Mexico City.

Table 1. Testing t. Vegetable consumption initial phase and final phase.

\begin{tabular}{cc}
\hline & Vegetable consumption \\
\hline IG & $\mathrm{T}=-8.910 \mathrm{p}=0.001$ \\
$\mathrm{CG}$ & $\mathrm{T}=-4.260 \mathrm{p}=0.001$ \\
\hline
\end{tabular}

status, in the final stage, it was found that adolescents who never ate vegetables were more likely to develop obesity (36.0\% IG and 36.10\% CG), compared with adolescents who consumed daily ( $8.9 \%$ IG and $2.10 \%$ CG), existing highly significant difference ( $p \leq$ 0.010) (Figure 4 and Figure 5).

\section{Discussion}

A prevalence of four out of ten adolescents with overweight and obesity, similar to the results documented by the Health and Nutrition Survey 2012 [8] where 35\% of 


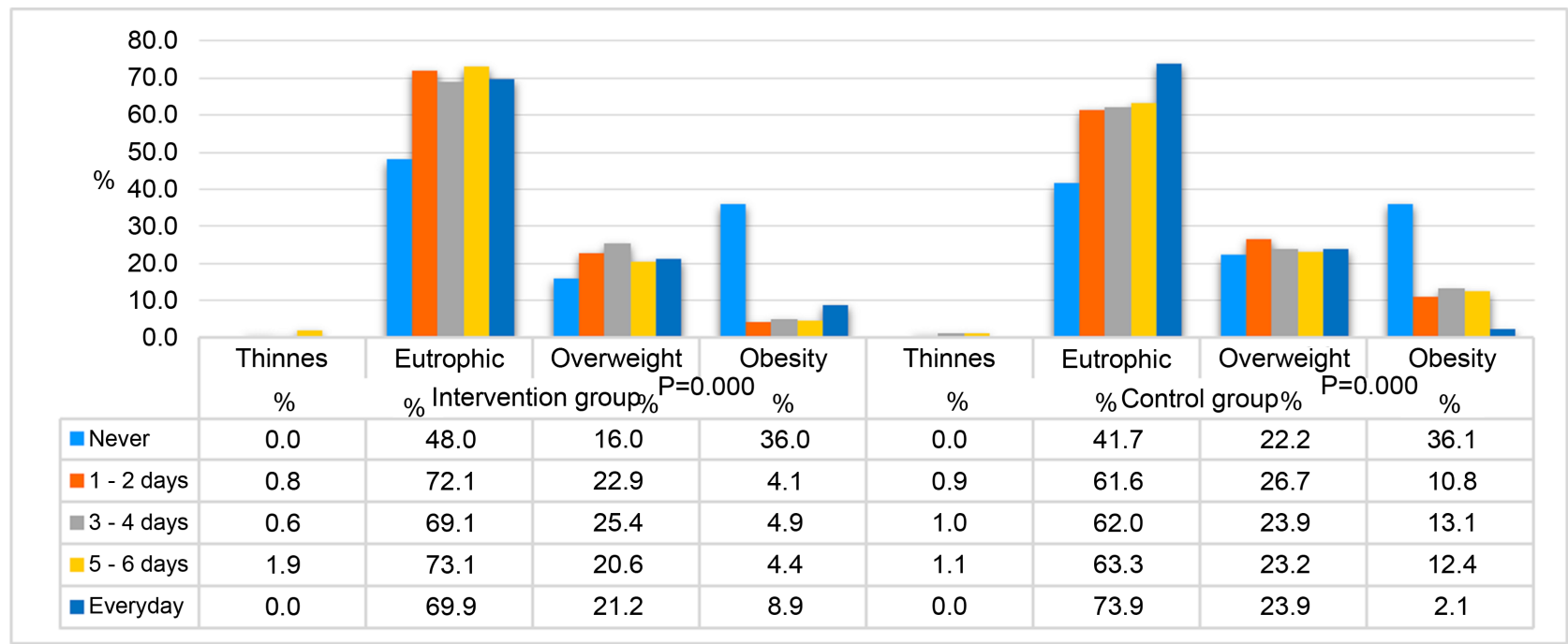

Figure 5. Frequency of vegetable consumption in relation to nutritional status in adolescents of the Technical High Schools in Mexico City. Final phase.

adolescents are overweight or obese. It also indicates that more than one in five adolescents are overweight and one in ten is obese.

Adolescents have a low intake of vegetables, similar to those reported by Milder et al. (2015) results. [9] Which reported that only $8.7 \%$ of adolescents consume vegetables daily, while $22.7 \%$ never consume them. Similarly Suarez et al. (2014) [10] reported that $20.3 \%$ of adolescents never consume vegetables, $55.4 \%$ consume only one or two daily servings of vegetables and only $24.3 \%$ consume more than two servings a day. The low consumption of vegetables is not exclusive to adolescents, but a reflection of what happens in the general population, Mexicans have a per capita consumption of $235 \mathrm{~g}$ of vegetables and fruits per day, on average, $58.75 \%$ over $400 \mathrm{~g}$ recommended by WHO [11]. Lazarus (2014) [12] reported an average consumption of $266 \mathrm{~g}$ of vegetables and fruits accounting for $66.5 \%$.

Association of overweight and obesity was found with low consumption of vegetables, low intake of vegetables is related to the lack of variety in the food groups. In addition, the low consumption of fruits, high consumption of canned, processed, industrialized beverages high in refined sugars, show a pattern of consumption tending to strengthen the so-called nutritional transition, which leads in turn to overweight and obesity [13] [14].

An increase was achieved in the consumption of vegetables in both groups, similar to those results reported by Fretes et al. (2013) [15] in their study of 59 parents and 59 school, where they made an intervention on the consumption of vegetables, in the initial phase had an average consumption of $103 \mathrm{~g}$ (IG), increasing to $122.5 \mathrm{~g}$ (IG) at the end of the intervention. However, in the CG they reported a decrease in consumption of vegetables, $99.9 \mathrm{~g}$ in the initial phase was reduced to $76.5 \mathrm{~g}$ in the final phase. Similarly, Gonzalez et al. (2014) [3] reported an increase in the consumption of vegetables in 976 children (784 IG and 192 CG) after an intervention in education of healthy eating 
in the IG in the initial phase they found that $13.2 \%$ of children never ate vegetables decrease to $7.8 \%$ achieved in the final phase.

\section{Conclusion}

It is concluded that the intervention was successful because it met the purpose of increasing the consumption of vegetables, however not satisfied with the WHO recommendation so it is recommended to design strategies to further increase their consumption of this way contributes to the prevention of obesity in adolescents. Since improving the eating habits of adolescents will favor the reduction of public health problems.

\section{References}

[1] Ochoa, M.G., Sierra, J.C., Pérez, R.C. and Aranceta, B.J. (2014) Validación del cuestionario Pro Children Project para evaluar factores psicosociales del consumo de fruta y verdura en México. Salud Pública Méx, 56, 165-179.

[2] Durán, A.S., Fernández, G.E., Fuentes, F.J., Hidalgo, F.A., Quintana, M.C., Yunge, H.W., Fehrmann, R.P. and Delgado, S.C. (2015) Patrones alimentarios asociados a un peso corporal saludable en estudiantes chilenos de la carrera de nutrición y dietética. Nutr Hosp, 32, 1780-1785.

[3] Parra, B.E., Manjarrés, L.M., Velásquez, C.M., Agudelo, G.M., Estrada, A., Uscátegui, R.M., Patino, F.A., Bedoya, G.J. and Parra, M.V. (2015) Perfil lipídico y consumo de frutas y verduras en un grupo de jóvenes de 10 a 19 años, según el índice de masa corporal. $R e V$ Colomb Cardiol, 22, 72-80.

[4] Freire, W.B., Ramírez, M.J., Belmont, P., Mendieta, M.J., Silva, M.K., Romero, N., Sáenz, K., Piñeiros, P., Gómez, L.F. and Monge, R. (2013) Encuesta Nacional de Salud y Nutrición del Ecuador. ENSANUT-ECU 2011-2013. Resumen ejecutivo tomo 1. Ministerio de Salud Pública.

[5] González, G.C.G., Zacarías, H.I., Domper, R.A. Fonseca, M.L., Lera, M.L. and Vio del, R.F. (2014) Evaluación de un programa de entrega de frutas con educación nutricional en escuelas públicas rurales de la Región Metropolitana, Chile. Revista Chilena de Nutrición, 41, 228-253. https://doi.org/10.4067/S0717-75182014000300001

[6] Araneda, F.J., Ruiz, N.M., Vallejos, V.T. and Oliva, M.P. (2015) Consumo de frutas y verduras por escolares adolescentes de la ciudad de Chillán. Chile. Revista Chilena de Nutrición, 42, 248-253. https://doi.org/10.4067/S0717-75182015000300004

[7] Restrepo, B.L.F., Holmes, R.E. and Deossa R.G.C. (2013) Consumo de vegetales y factores relacionados en estudiantes universitarios de la ciudad de Medellín, Colombia. Perspect Nutr Humana, 15, 171-183.

[8] Gutiérrez, J.P., Rivera, J., Shamah, T., Villalpando, S., Franco, A., Cuevas, L., Romero, M. and Hernández, M., (2012) Encuesta Nacional de Salud y Nutrición 2012. Resultados Nacionales. Cuernavaca, México: Instituto Nacional de Salud Pública (MX).

[9] Milder, B.L.E., Castro, M.A.Y., Dias de Almeida, O.E.D., Sanches, M.D.K., Dias, M.I. and Jardim, F.E. (2015) Hábitos alimentares saudáveis versus níveis pressóricos, emadolescentes residentes Em Itaqui. RS. Capa; 7 (2): Pôster. Salão de Pesquisa. http://publicase.unipampa.edu.br/index.php/siepe/article/view/15663

[10] Suárez-Varela, M.M., Ruso, J.C., Micó, G.A. and Llopis, G.A. (2014) Valoración del patrón alimentario en adolescentes españoles en zona mediterránea y atlántica: Un estudio piloto. Rev Esp Nutr Comunitaria, 20, 85-90. 
[11] González, G.S. (2015) Mexicanos comen sólo 58\% de las frutas y verduras recomendables al día. La jornada.

http://www.jornada.unam.mx/ultimas/2015/02/18/mexicanos-comen-solo-58-de-frutas-y-v erduras-recomedables-al-dia-3009.html

[12] Lázaro, M. (2014) Guías alimentarias para la población peruana. http://www.ins.gob.pe/repositorioaps/0/0/not/temdif32599/PPT\%20Gu\%C3\%ADas\%20ali mentarias.pdf

[13] Marín, C.A.D., Sánchez, R.G. and Maza, R.L.L. (2013) Prevalencia de obesidad y hábitos alimentarios desde el enfoque de género: el caso de Dzutóh, Yucatán, México. Estudios Sociales, 22, 63-90.

[14] FAO. Organización de las Naciones Unidas para la Alimentación y la Agricultura (2014) Panorama de la Seguridad Alimentaria y Nutricional en América Latina y el Caribe 2013. http://www.fao.org/docrep/019/i3520s/i3520s.pdf

[15] Fretes, G., Salinas, J. and Vio, F. (2013) Efecto de una intervención educativa sobre el consumo de frutas, verduras y pescado en familias de niños preescolares y escolares. Archivos Latinoamericanos de Nutrición, 63, 37-45.

Submit or recommend next manuscript to SCIRP and we will provide best service for you:

Accepting pre-submission inquiries through Email, Facebook, LinkedIn, Twitter, etc.

A wide selection of journals (inclusive of 9 subjects, more than 200 journals)

Providing 24-hour high-quality service

User-friendly online submission system

Fair and swift peer-review system

Efficient typesetting and proofreading procedure

Display of the result of downloads and visits, as well as the number of cited articles

Maximum dissemination of your research work

Submit your manuscript at: http://papersubmission.scirp.org/

Orcontact fns@scirp.org 